\title{
TAX EVASION BETWEEN FRAUD AND LEGALITY
}

\section{Laura-Anca Opreț}

Ph.D. Student, University of Economic Studies, Bucharest, Romania ancaopret@yahoo.com

\section{Florin Marius Turcaş}

Ph.D. Student, University of Economic Studies, Bucharest, Romania turcasflo@gmail.com

\section{Florin-Cornel Dumiter}

Professor Ph.D., Faculty of Economic Sciences, "Vasile Goldiş" Western University of Arad, Arad, Romania, fdumiter@yahoo.com

\section{Petre Brezeanu}

Professor Ph.D, Finance Doctoral School, Bucharest University of Economic Studies, Bucharest, Romania brezeanupetre@yahoo.com

(Received, July 2017; Accepted November 2017)

\begin{abstract}
This paper focuses on detailing the general coordinates regarding tax evasion and the necessity of creating a common unitary European legal framework. Accounting information might mirror erroneously in a certain measure the micro to macroeconomic tendency of fraud by showing a gross image of available resources. It is of the utmost importance to become fully aware of causes for illicit practices, ways to fight any fraud attempts and to evaluate the accounting mechanism that both creates and identifies tax evasion.
\end{abstract}

Keywords: tax evasion, legal framework, accounting information, tax compliance.

\section{Introduction}

The genesis of tax evasion is ultimately connected to the state and its apparition is mentioned by contemporary economists as 'Tax evasion was born together with the state and it will die with it'.

In our history, tax evasion evolved as society has evolved in general both socially and economically. Withdrawing from paying taxes has historically been a concern of those taxed upon. The multitude of paying obligations that fiscal legislation impose on tax payers likewise the burden of those taxes have made and stimulated the ingenuity of tax payers to find and exploit specific loopholes in not paying taxes at all or at least in a greatly diminished amount (Brezeanu, 2005). 
Opret L.A., Turcaş F.M., Dumiter F.C., Brezeanu P. (2017)

Tax evasion between fraud and legality

'Tax fraud has always been extremely active and ingenious mainly because regulators always hit people where it mattered the most. Their money and their finances.' Tax evasion represents 'withholding through any means fully or partially from paying taxes, fees and other amounts due to state budget, local budget, the social security budget and special extra budgetary funds, by both individuals or legal entities foreign or national'(Law no. 241/2005 replacing Law no. 87/1994).

Tax evasion is characterized by a very large inaccuracy, associating three ways and a double appreciation in terms of legality. The first meaning that has been attributed to tax evasion, especially between the two world wars, was that fraud is understood in an extensive form, that the notion of tax evasion is included in that of fraud, this being sustained by Lerouge and M.A. Piatier.

The most widely understood meaning in which tax evasion is known as 'the art to avoid falling into the field of tax law', concept which belongs to C.M. de Brie and P. Charpentier. According to this perception, tax evasion is somehow assimilated to fraud.

The third meaning is a generic term and designates all events of 'fleeing' from paying taxes. This broad definition of tax evasion that includes tax fraud is sustained by Maurice Duverger.

Tax evasion is a logical result of defects and inadvertences of imperfect and badly assimilated legislation, faulty implementing methods and lack of vision and excessive taxation from law makers that provokes tax payers to elude paying their due contribution (Anghelache, 2003).

Looking back to this phenomenon, we can say without being wrong, that tax evasion is as old and common in society just as old as the existence of the state and tax laws. The field of tax evasion is as wide, broad and varied as the field of taxation. However, it is manifested, especially in the field of direct taxation, influencing their performance. Tax evasion is one of the complex socio-economic phenomena of utmost importance that countries face today and which unwanted consequences they seek to limit them as much as possible, whilst eradication is practically impossible. The state should focus systematically and efficiently in hindering and on limiting tax evasion. The state through public authorities can incite to tax evasion, following two main purposes: a 'positive' purpose supported by the desire to stimulate capital formation and a 'negative' one reflected in the support of certain interest groups, often mafia type, with all the consequences implied.

The many fiscal obligations that the law imposes on tax payers, and especially the burden of these commitments were made to stimulate at all times, taxpayers ingenuity in inventing different methods to circumvent tax obligations. Tax evasion has always been particularly active and ingenious. 
In a market economy, tax authorities face an escapist phenomenon that has mass proportions because of the tendency to divert from under the law mainly large sums and income. The proliferation of illegal acts, especially those in the field of finance and business, is a consequence of poor legislation or lack of proper regulation.

The means for avoiding tax liabilities is presented in innumerable forms, but they can be divided into the following categories:

- illicit acts;

- simple lying or using legal loopholes;

- intentional.

\section{Fighting Tax Evasion}

Tax evasion evolved by the combined action of certain factors such as: the dynamics of the real economy, the quantitative and qualitative size of the legal and institutional framework, the level of taxation, and other internal or external factors. Escapist phenomenon is complex, with negative implications in many fields and, as such, it must be continually monitored to be combated more effectively (Minea, 2005).

International tax practice proves that a modern tax system should have behaviours that lead to prompt informing and educating taxpayers about their obligations, regarding the correct preparation of tax returns, the keeping of accurate income and expenses records arising from activities and penalties \& sanctions applicable to those who violate the law (Balaban, 2003).

Amongst the measures that can contribute to limiting tax evasion in Romania we can mention the following:

- unification of tax legislation and better coordination with the legislative package concerning economy;

- elimination of provisions in acts that may encourage tax evasion and better correlation of tax incentives;

- reorganization of territorial structures of the Ministry of Public Finance, so as to eliminate duplication and overlap of activity of the financial and fiscal control, in terms of fiscal supervision, fiscal control and combating tax evasion;

- increase the use of control by exception (sampling) and mandating as exemplary the mean of permanent control;

- editing of specialized publications by the Ministry of Finance to facilitate uniform interpretation of the regulatory framework on identifying and combating tax evasion; 
Opret L.A., Turcaş F.M., Dumiter F.C., Brezeanu P. (2017)

Tax evasion between fraud and legality

- the establishment of a report which strives to become optimal between salaries and incentives for the fiscal apparatus;

- creating a centralised database of the Ministry of Finance to show whether a certain legal is in debt to the state budget or not;

- improving the training of personnel involved in preventing, detecting and combating tax evasion;

- $\quad$ adopting a taxation rate at an optimal level;

- lower inflation;

- $\quad$ increasing employability;

- $\quad$ seizing and confiscation or unreported values.

\subsection{Methods to prevent tax evasion according to Law 241/2005:}

Obligations provided for taxpayers to prevent tax evasion facts are the most diverse:

- conducting permanent or temporary activities generating taxable income, can only take place under a permit issued by the competent body or other grounds provided by law;

- the obligation to declare, to the tax body within five days of registration documents in connection with subunits constituted in subsidiaries, branches, outlets, warehouses, stores and any other places where income-producing activities are held, banks in lei or foreign currency wherever these might be in the country or abroad;

- the obligation to declare honestly income, movable and immovable property owned or obtained with any legal title and other securities that generate tax receivable titles. When the law does not require the submission of the tax, taxpayers are responsible for correct calculation of the taxes that have to pay to the budget;

- term obligation to pay the taxes due on taxable income or assets;

- the obligation to allow inspection and to allow control authorities by making available all accounting documents, records and any other content or value required in order to know the reality of objects or taxable sources/taxable;

- the obligation to declare to the supervisory body goods or taxable values stored in places other than those performing in producing revenue.

\section{Evolution of the Tax System in Romania during 2006 - 2016 period}

Fiscal policy measures promoted by the tax authorities in our country in the 20062016 period, along with other factors such as quality management of state tax claims and the degree of voluntary compliance to tax, influenced the volume and 
Opreț L.A., Turcaș F.M., Dumiter F.C., Brezeanu P. (2017)

Tax evasion between fraud and legality

structure of tax revenue and the pressure carried by them (EU Commission Report, 2016).

Table 1 presents the evolution of gross domestic product and tax revenue of Romania and the level of taxation in the period 2006-2016.

Evolution of the tax system in Romania during 2006-2016

Table 1

\begin{tabular}{|c||c|c|c|c||}
\hline Year & $\begin{array}{c}\text { Gross domestic } \\
\text { product }\end{array}$ & $\begin{array}{c}\text { Fiscal } \\
\text { income }\end{array}$ & $\begin{array}{c}\text { Level of general } \\
\text { taxation }(\%)\end{array}$ & $\begin{array}{c}\text { Level of partial } \\
\text { taxation (\%) }\end{array}$ \\
\hline \hline$(\mathbf{1})$ & $(\mathbf{2})$ & $(\mathbf{3})$ & $\mathbf{( 4 )}$ & $\mathbf{( 5 )}$ \\
\hline $\mathbf{2 0 0 6}$ & $7.213,6$ & $2.080,3$ & 28,8 & 20,7 \\
\hline $\mathbf{2 0 0 7}$ & $10.891,9$ & $2.925,6$ & 26,9 & 19,4 \\
\hline $\mathbf{2 0 0 8}$ & $25.292,6$ & $6.700,0$ & 26,5 & 19,6 \\
\hline $\mathbf{2 0 0 9}$ & $37.379,8$ & $10.541,1$ & 28,2 & 20,0 \\
\hline $\mathbf{2 0 1 0}$ & $54.573,0$ & $16.402,6$ & 30,1 & 19,5 \\
\hline $\mathbf{2 0 1 1}$ & $80.377,3$ & $23.504,8$ & 29,3 & 18,6 \\
\hline $\mathbf{2 0 1 2}$ & $116.768,7$ & $32.669,9$ & 28,0 & 17,5 \\
\hline $\mathbf{2 0 1 3}$ & $151.475,1$ & $41.816,6$ & 27,6 & 17,0 \\
\hline $\mathbf{2 0 1 4}$ & $190.335,4$ & $53.248,2$ & 28,0 & 18,2 \\
\hline $\mathbf{2 0 1 5}$ & $238.791,4$ & $66.678,3$ & 27,9 & 18,5 \\
\hline $\mathbf{2 0 1 6}$ & $287.186,3$ & $78.281,4$ & 27,3 & 18,0 \\
\hline
\end{tabular}

Legend:

(2) million lei, current prices;

(3) taxes and contributions collected at the general consolidated budget, million lei, current prices;

$(4)=(3) /(2) ;(5)=\frac{\text { Taxes }}{G d p} * 100$.

Source: Public Finance Ministry, www.mfinanţe.ro

During the period considered, the level of general taxation, calculated by taking into account all taxes and contributions collected by central and local public authorities, recorded, except for 2009 and 2010, a continuous downward trend, from $28.8 \%$ in 2006 to $27.3 \%$ in 2016 . Overall, the level of general taxation decreased during the period considered by around 1.5 percentage points.

The tax burden determined solely on the basis of revenue received from taxes fluctuated around $20 \%$ during 2006-2011, then stabilized at around $18 \%$ at the end of the review period. In the period 2006-2016, fiscal pressure tax and reduced by about 3 percentage points.

Reducing the tax burden, 2006-2009, it can be assessed as being related to the decline in the real economy, with the continuous decrease in real terms of GDP and, consequently, diminishing tax base. Also, changes in the level of taxation are 
Opret L.A., Turcaş F.M., Dumiter F.C., Brezeanu P. (2017)

Tax evasion between fraud and legality

determined by the evolution of the collection of compulsory levies in close connection with the voluntary compliance of taxpayers to pay them.

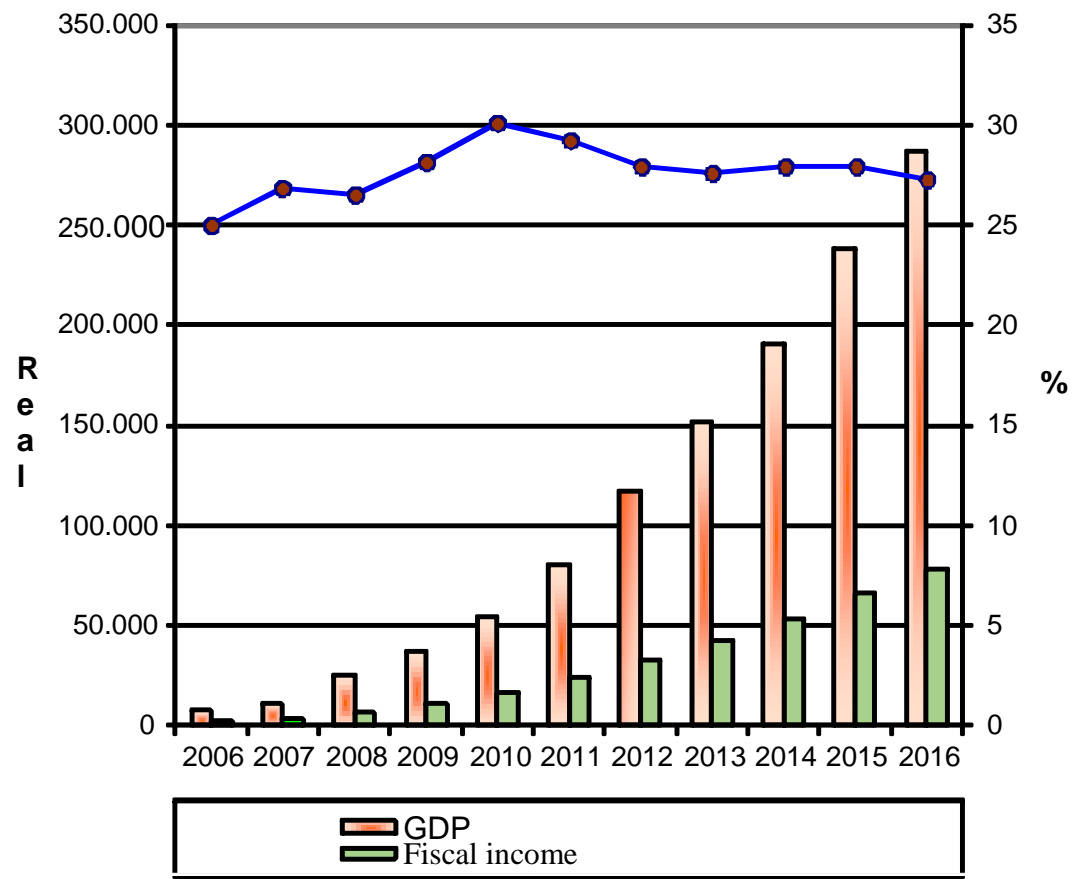

Figure 1. Evolution of the taxation level in Romania (2006-2016)

Given that, after 2011, GDP began to grow from year to year, in real terms, the trend of decreasing level of taxation can be considered as a result of the general trend manifested fiscal relaxation in past five years. As an example may be mentioned in this connection the reduction from $1^{\text {st }}$ January 2012 the profit tax rate from $38 \%$ to $25 \%$ and then to $16 \%$, starting from $1^{\text {st }}$ January 2011 , also reducing from $1^{\text {st }}$ January 2006 , the standard rate of VAT from $22 \%$ to $19 \%$ and reducing fiscal pressure exerted by social security contributions from 55\% in 2009 to $49 \%$ in 2016.

\section{Evolution of taxation levels in EU Member States between 2008 - 2016 period}

In order to clearly identify where Romania is situated in comparison with other EU member states we can present in Table 12 total fiscal income in EU member states in 2000, 2008, 2015 and 2016. 
Opret L.A., Turcaș F.M., Dumiter F.C., Brezeanu P. (2017)

Tax evasion between fraud and legality

During these years general taxation levels in these countries have been situated above general taxation levels in Romania. The difference between general taxation levels in Romania and in the EU member states has been approximately 11 percent. Even in central European countries, members of the EU have a significantly higher degree of general taxation levels than Romania, so much as $37.7 \%$ in the Czech Republic, 38.5\% in Hungary, 34.2\% in Poland, 31.1\% in Slovakia and 34.2\% in Slovenia as compared to $28 \%$ in Romania (EU budget 2010 Financial Report).

Table 2

Total fiscal income as a percentage of EU member states national GDP

\begin{tabular}{|l||c|c|c|c||}
\hline \multicolumn{1}{|c|}{ Member state } & $\mathbf{2 0 0 0}$ & $\mathbf{2 0 0 8}$ & $\mathbf{2 0 1 5}$ & $\mathbf{2 0 1 6}$ \\
\hline \hline Austria & 41,1 & 42,6 & 43,6 & 43,1 \\
\hline Belgium & 44,8 & 45,7 & 46,2 & 45,4 \\
\hline Czech Republic & 37,5 & 36,0 & 37,0 & 37,7 \\
\hline Denmark & 49,5 & 50,1 & 48,7 & 48,3 \\
\hline Finland & 46,0 & 48,0 & 45,8 & 44,8 \\
\hline France & 42,9 & 44,4 & 43,4 & 43,4 \\
\hline Germany & 37,2 & 37,2 & 35,4 & 35,5 \\
\hline Greece & 32,4 & 38,2 & 37,1 & 35,7 \\
\hline Hungary & 42,4 & 39,0 & 38,8 & 38,5 \\
\hline Ireland & 32,8 & 32,2 & 28,7 & 29,7 \\
\hline Italy & 41,2 & 43,2 & 42,5 & 43,1 \\
\hline Luxemburg & 42,3 & 40,6 & 41,3 & 41,3 \\
\hline Netherlands & 41,9 & 41,2 & 39,2 & 38,8 \\
\hline Poland & 37,0 & 32,5 & 34,7 & 34,2 \\
\hline Portugal & 33,6 & 36,4 & 36,5 & 37,1 \\
\hline Romania & 28,8 & 29,3 & 27,6 & 28,0 \\
\hline Slovakia & & 34,3 & 33,0 & 31,1 \\
\hline Spain & 31,8 & 34,8 & 34,8 & 34,9 \\
\hline Sweden & 48,5 & 53,9 & 50,1 & 50,6 \\
\hline United Kingdom & 35,1 & 37,5 & 35,6 & 35,6 \\
\hline \multicolumn{2}{|c|}{ Source: OECD site, www.oecd.org } & \\
\hline
\end{tabular}

Given that the level of taxation is determined on actual tax revenues, low taxation levels might be explained by a poor collection of taxes and with a high level of circumventing taxation to which may be added numerous tax incentives granted over time. At a rate of taxation overall, less than $30 \%$ of gross domestic product in Romania, we cannot speak of excessive taxation. Moreover the trend that currently exists at national level is to reduce levels of taxation. However, it is noted that this level of taxation was determined based on tax revenue actually collected and not those due or stolen consolidated budget tax revenues are not taken into account and are virtually impossible to commensurate to their true level.

DE GRUYTER OPEN
Studia Universitatis "Vasile Goldis" Arad. Economics Series Vol 27 Issue 4/2017 ISSN: 1584-2339; (online) ISSN: 2285 - 3065

Web: publicatii.uvvg.ro/index.php/studiaeconomia.Pages $1-1$ 
Opreț L.A., Turcaș F.M., Dumiter F.C., Brezeanu P. (2017)

Tax evasion between fraud and legality

\section{The structure $f$ Tax Levies in Romania in 2006 - 2016 period}

For a complete picture of the distribution of the tax burden in our country, we are shown Table 3 the weight of the main categories of tax revenue to gross domestic product in 2006-2016.

Table 3

Structure of fiscal income in Romania, percentage in GDP (2006-2016)

\begin{tabular}{|c||c|c|c|c|c|c|c|c|}
\hline \hline Year & $\begin{array}{c}\text { Direct } \\
\text { TAX }\end{array}$ & $\begin{array}{c}\text { Profit } \\
\text { TAX }\end{array}$ & $\begin{array}{c}\text { Salaries } \\
\text { tax }{ }^{1} / \text { income }\end{array}$ & $\begin{array}{c}\text { S. security } \\
\text { contributions }\end{array}$ & $\begin{array}{c}\text { Indirect } \\
\text { TAX }\end{array}$ & VAT & $\begin{array}{c}\text { ICM and } \\
\text { ex. Duties }\end{array}$ & $\begin{array}{c}\text { Custom } \\
\text { duties }\end{array}$ \\
\hline \hline$(1)$ & $(2)$ & $(3)$ & $(4)$ & $(5)$ & $(6)$ & $(7)$ & $(8)$ & $(9)$ \\
\hline 2006 & 19,5 & 3,9 & 6,4 & 8,1 & 9,3 & 5,2 & 1,5 & 1,4 \\
\hline 2007 & 18,0 & 3,3 & 6,1 & 7,5 & 8,9 & 4,9 & 1,4 & 1,5 \\
\hline 2008 & 17,5 & 4,3 & 5,5 & 6,9 & 9,0 & 4,6 & 1,7 & 1,3 \\
\hline 2009 & 17,2 & 3,0 & 5,0 & 8,2 & 11,0 & 6,1 & 2,3 & 1,9 \\
\hline 2010 & 18,5 & 3,1 & 3,3 & 10,6 & 11,6 & 6,0 & 3,1 & 1,4 \\
\hline 2011 & 17,7 & 2,5 & 3,4 & 10,7 & 11,6 & 6,3 & 2,6 & 1,1 \\
\hline 2012 & 16,9 & 1,9 & 3,2 & 10,5 & 11,1 & 6,3 & 2,3 & 0,8 \\
\hline 2013 & 16,5 & 2,0 & 2,8 & 10,6 & 11,2 & 6,9 & 2,1 & 0,6 \\
\hline 2014 & 15,8 & 2,3 & 2,8 & 9,8 & 12,2 & 7,2 & 3,2 & 0,7 \\
\hline 2015 & 16,0 & 2,7 & 3,0 & 9,4 & 11,9 & 6,9 & 3,3 & 0,7 \\
\hline 2016 & 14,8 & 2,3 & 2,3 & 9,3 & 12,5 & 7,8 & 3,2 & 0,7 \\
\hline
\end{tabular}

${ }^{1}$ Starting from 2006 - global income tax.

Source: Public Finance Ministry, www.mfinanţe.ro

We see a reduction in the contribution of direct taxes respectively indirect growth if we consider gross domestic product. The share of direct taxes in the GDP has decreased continuously in the period, from $19.5 \%$ in 2000 to $14.8 \%$ in the current period. In part, the difference was taken from indirect taxes, whose share increased from $9.3 \%$ in 2006 to $12.5 \%$ in 2016 .

Maintaining a higher share of direct taxes compared to indirect, is due solely to social security contributions.

Given that direct taxes are characterized by a high degree of sensitivity to fluctuations in the economy, increasing the share of indirect taxes in total public revenues shows that when the economy does not work, due to economic and social bottlenecks so for the State authorities the safest income source is to tax consumption, especially since this is the only way to create income in the underground economy that may be taxable. This type of tax is preferable because in terms of a low wealth and income individuals and businesses they can have a high tax yield, but also because of convenience and relatively low cost of collecting them.

The reduced level of taxation in Romania, while the tax rates for the main taxes are

8 DE GRUYTER OPEN
Studia Universitatis "Vasile Goldis" Arad. Economics Series Vol 27 Issue 4/2017 ISSN: 1584-2339; (online) ISSN: 2285 - 3065

Web: publicatii.uvvg.ro/index.php/studiaeconomia.Pages $1-11$ 
Opret L.A., Turcaș F.M., Dumiter F.C., Brezeanu P. (2017)

Tax evasion between fraud and legality

similar to those practiced by other countries in Eastern Europe, indicate a weak collection of due taxes and levies, mainly the phenomenon of evasion from tax obligations.

Continued decline in the level of taxation in Romania after 2013, amid growth in real and gross domestic product respectively, reducing tax rates for the main taxes can be explained either by the fact that the increase in the tax base is not sufficient to offset the loss of revenue due to reduction in tax rates, either by decreasing drastically the level of tax compliance and tax evasion phenomenon expansion.

Although generally similar, tax policy in Romania was perceived by the taxpayer to be high, especially by individuals employed, where social security contributions were located, most often at the highest level compared with other countries in Central and Eastern Europe

Structural analysis shows a decrease in compulsory levies, while the share of direct taxes in total tax revenues, and an increase in the indirect preferred due to their higher efficiency, including in less prosperous times economically, but deeply unfair to the taxpayers-individuals.

The conclusion is that in Romania, during 2006-2016, the tax burden on the shoulders pressed especially individuals, both by high labour taxation and through indirect taxation, thereby causing a significant decline in the level of tax compliance for this category by taxpayers.

\section{Conclusions}

Tax evasion today is a scourge that affects all countries to some extent, regardless of the degree of economic development, its effects are disastrous for the economy with serious consequences, so in this regard is a careful observation of all economic activities carried out and taking measures to protect both the national and the international economy.

The existence of legislation which minimizes tax evasion is imperative, the existence of accounting information as an active factor in determining the phenomenon make it accessible identifying tax evasion; accounting information liaise direct with primary documents "proving" intent manufacture or production of tax evasion.

Tax evasion seen as a whole identify themselves as a phenomenon of nonaccounting principles, management principles necessary for any organization, entity or micro or macroeconomic entire system.

In the case of our country, as the country entered the EU in 2007, fiscal policy should include a strong future repression of the shadow economy, corruption, economic crime and fraud.

Studia Universitatis "Vasile Goldis" Arad. Economics Series Vol 27 Issue 4/2017 ISSN: 1584-2339; (online) ISSN: $2285-3065$

Web: publicatii.uvvg.ro/index.php/studiaeconomia.Pages $1-11$ 
Opret L.A., Turcaş F.M., Dumiter F.C., Brezeanu P. (2017)

Tax evasion between fraud and legality

Promoting strategic objectives of fiscal policy, while streamlining fiscal control, should improve fiscal discipline, have the effect of increasing the amount of taxes collected and reduce corruption and increase efficiency in the recovery of amounts derived from tax evasion.

Extremely harmful, unusual and condemnable phenomenon, tax evasion has been and is an unwanted presence with trends and incidences, different in any country, regardless of size, level of development, political system or governance mechanisms.

From electoral polemics, doctrine, specialized practice and the media, tax evasion legislation has produced and still produces numerous debate.

For many analysts, tax evasion is one of the diseases of companies modern, along with the underground economy, corruption and others, and for others, few in number, it is an attitude, a manifestation of democracy. Like any phenomenon complex, tax evasion can not be easily explained, and all the more eradicated.

Regardless of how this phenomenon was defined, tax evasion is, in fact, the failure of the taxpayer to meet his tax obligations established by law. Regardless of the method adopted, at the macroeconomic level tax evasion produces major imbalances, with a decisive impact on evolution the economy of any country.

The importance of reducing the phenomenon of tax evasion derives, firstly the fact that public revenues consist of taxes and duties paid to the state, and this revenue is financed by public expenditure, ie:

- Health;

- Education;

- Cultural activities;

- National security;

- Social activities;

- Other public services.

The phenomenon of tax evasion has always existed and certainly will there is also in the future, however, its dimensions, considered very high, due to information and data that are far too relevant can be accurately determined never.

\section{References}

[1] Anghelache G., Beleanu, P., (2003), Finanţele publice ale României, Editura Economică, Bucureşti.

[2] Anghelache C., (2005), România 2005- Starea economică la a câta schimbare?, Bucureşti, Editura Economică.

[3] Balaban, C., (2003), Evaziune fiscală- Aspecte controversate de teorie şi practică judiciară, Bucureşti, Editura Rosetti.

[4] Beju, V., (2006), Resursele financiare publice- Evaziunea fiscală şi corupţia, ClujNapoca, Editura Casa Cărţii de Ştiinţă. 
Opret L.A., Turcaș F.M., Dumiter F.C., Brezeanu P. (2017)

Tax evasion between fraud and legality

[5] Beju, V., (2002), Metode şi tehnici fiscale, Târgu Mureş, Editura Dimitrie Cantemir.

[6] Beleanu, P., Anghelache, G. (2005), Finanţe publice, Editura Economică, București

[7] Brezeanu P., Şimon I., Celea, S., (2005), Fiscalitate europeană, Bucureşti, Editura Economică.

[8] Dăianu, D., Vrânceanu, R., (2000), România şi Uniunea Europeană - inflaţia, balanţa de plăţi, creşterea economică, Editura Polirom, Bucureşti

[9] Hoanţă N., (2000), Economie şi finanţe publice, Iaşi, Editura Polirom.

[10] Lazăr, D.T., Inceu, A., Moldovan, B., (2009), Finanţe şi bugete publice, ediţia a 3-a, Editura Accent, Cluj-Napoca

[11] Minea Ş.M, Chiriac L.T, Costaş, F.C., (2005), Dreptul finanţelor publice, Cluj Napoca, Editura Accent.

[12] Moraru Dan, Mihai Nedelescu, oana Preda, Cristina Stănescu, (2006), Finanţe publice, Bucureşti, Editura Economică.

[13] Moșteanu, T., Finanţe publice - note de curs şi aplicaţii pentru seminar - ediţia a III-a revizuită, Editura Universitaria, București, 2011.

[14] Rosen, H., (2005), Public Finance, Editura McGraw-Hill International Edition

[15] Schneider, F., (2011), The shadow economy in Europe, University of Linz, Austria

[16] Văcărel I., (2007), Finanţe publice, Editura Didactică și Pedagogică, București

[17] Studii financiare (Financial Studies), 2008, vol. 12, issue 14, pp.20-50

[18] *** European Comission (2014), Annual Growth Survey, Brussels

[19] *** European Budget 2010 Financial Report, Brussels

[20]*** Revista tinerilor economişti, (2004), An II-Nr.3, Universitatea din Craiova, Facultatea de ştiinţe economice.

[21]*** Revista „eFinance”, (2006-decembrie), Bucureşti.

[22]*** Revista „Euroconsultanţa - Ghidul firmei”, (2006) noiembrie - decembrie, Bucureşti.

[23] $* * *$ http://www.efinance.ro/

[24] $* * *$ http://www.finint.ase.ro/

$[25] * * *$ http://www.ier.ro/

[26] $* * *$ http://www.infoeuropa.ro/

[27] $* * *$ http://www.insse.ro/

[28]*** http://www.oecd.org

[29] *** http://www.mfinanţe.ro/

[30] $* * *$ http://www.eurostat.ro

Studia Universitatis "Vasile Goldis" Arad. Economics Series Vol 27 Issue 4/2017 ISSN: 1584-2339; (online) ISSN: 2285 - 3065 